\title{
An Empirical Study on Visibility of Conspicuous Consumption Motives of Consumers in Jaffna, Sri Lanka
}

\author{
Sinnathurai Vijayakumar and Olga Brezinova
}

\begin{abstract}
Jaffna, Sri Lanka is experiencing major shifts in her socio-cultural structure during the last ten years. Especially after post war, consumer behavior and patterns has rapidly changed in Jaffna. Thus, a society which has been traditionally known as "collective" in nature is showing increased evidence of individualism. With increased penetration of electronic media, affordable home entertainment systems, cinema, and the internet, consumers are opening up to the great outside world. The developed worlds are constantly creating reality for the consumers. This is not different in case of Jaffna. Having finished civil war, people in Jaffna are more enthusiastic to imitate others because of seeking social status and they Strive to show the impression that they are better off than before. Not only that they increase his chance of making relationship with high ability and middle and upper class people. The main objectives of the present study were to find out the significant determinants for conspicuous consumption and size of that between male and female and to what extend poor tend to display their conspicuous consumption in a society. For this study, OLS method and descriptive statistics have been used with the help of statistical software for social science (SPSS). The results bring the light the fact that income is main determinant of the amount to be allocated but sex and age have insignificant impact on the amount to be allocated for social status. Further, this finding clearly shows the fact that people in Jaffna are making significant allocation of their income to maintain social status than satisfaction and at the same time, poor people in Jaffna are also enthusiastic to have conspicuous consumption for expressing their position that they are better off than before. This study will be giving different insight to researchers and policy makers because the literature for conspicuous consumption pays little attention on poor and low middle income people yet, especially in Sri Lanka. Further, this study will help to marketing managers or firms in their decision about sales.
\end{abstract}

Index Terms-Conspicuous consumption, social status, poor people, income, age.

\section{INTRODUCTION}

Commodities do not only serve the purpose of satisfying direct needs in the production and consumption process. Some of them are also used to display social status and to affect the position of an individual in society. Several economists have maintained that consumers' concern for social status has important economic consequences. Veblen (1899) argued that Wealthy individuals often consume highly conspicuous goods and services in order to advertise their wealth and thereby achieving concern for social status

Manuscript received March 9, 2012; revised May 05, 2012.

S. Vijayakumar and O. Brezinova are with Tomas Bata University, Faculty of Economics and Management, Czech Republic (email:vijai_70@yahoo.co.in). which induces people to engage in conspicuous consumption in order to signal wealth [1]. Keynes (18831946) argued that consumption of households depends upon their absolute income or current income [2]. Namazie and Sanfey (2001) confirm that personal comfort depends strongly on the absolute level of income of the household to which one belongs [3]. Powdthavee (2003) also stated that absolute income matters significantly in the evaluation of well-being [4]. Dusenberry (1949) argued that a concern for status causes people to imitate the consumption standard of those above them in the income hierarchy. Moreover, Dusenberry (1949) in his study of relative income hypothesis emphasizes that relative income plays the crucial role in determining the consumption of individual because everybody strives to imitate consumption of neighbors relative and colleagues. Thus, Dusenberry contended that an individual is less concerned with absolute level of consumption than by relative levels of income. In other words, briefly, it is function of relative income [5]. Graham and Pettinato (2002) argue that the absolute income is not the sole determinant of satisfaction among the poor. According to Graham and Pettinato (2002,), "relative income differences are, no doubt, influencing the wellbeing". This implies that people's comfort is influenced by their relative positions in a society than their absolute income [6]. Generally, consumer behavior theory describing the market behavior of consumer is based on some basic assumption in which the absence of conspicuous consumption is sole one. But, validity of this assumption has not been supported through empirical inquiry which confirms the importance of conspicuous motivation in consumer behavior; the conspicuous consumption belongs to not only rich consumers but also poor and low middle income people. Therefore, in Sri Lanka, little research has been made on particular issue. Not only that people in Jaffna strive to imitate relatives, neighbors and the people of high class and at the same time, foreign remittance receiving from their relatives who live in Europe and Canada has been flowing to Jaffna. This is also one of the reasons for increasing purchasing capacity of people of Jaffna. Under this backdrop, researcher tries to bring the new insight to the society in regard to conspicuous consumption by doing research.

\section{OBJeCtives of StUdy AND MEthodOlOGY}

In addition to people of middle income, poor also has conspicuous consumption in their behavioral character while purchasing good and services. Jaffna is experiencing major shifts in her socio-cultural structure after post -war. Thus, a society which has been traditionally known as 
"collective" in nature is showing increased evidence of individualism .With increased penetration of electronic media, affordable home entertainment systems, cinema, and the internet, consumers are opening up to the great outside world. Visual images, like elsewhere in the developed world are constantly creating reality for the consumers [7]. By investing in social status they increase his chance of making relationship with high ability people and they strive to display their status. By interpreting status consumption as an ability signal, the present paper provides new insight to the literature of conspicuous consumption. Thus, the paper tries to focus on the behavior of both low middle income people and poor in Jaffna, Sri Lanka in regard to their conspicuous consumption. The people of low middle income and poor are more willingness and enthusiastic to purchase durable and related goods due to status seeking even though income is limited. Jaffna people strive to imitate in consuming goods and services with their relatives, neighbors and colleagues .Further, people strive to combat the impression that they are poor. Therefore, main objectives of this study are to identify the significant variables determining the amount to be allocated for social status, to find out the size of conspicuous consumption between male and female and to what extend the poor and low middle income people spend on conspicuous consumption and to what extent people concentrate the status seeking than satisfaction of consuming goods.

\begin{tabular}{|c|c|c|}
\multicolumn{3}{c}{ TABLE I: SAMPLE PROFILE } \\
\hline \multirow{3}{*}{ Sex } & Male & \multicolumn{1}{|c|}{} \\
\cline { 2 - 3 } & Female & $40 \%$ \\
\hline \multirow{4}{*}{ Age } & $15-20 \mathrm{yrs}$ & $6.3 \%$ \\
\cline { 2 - 3 } & $21-30 \mathrm{yrs}$ & $32.7 \%$ \\
\cline { 2 - 3 } & $31-50 \mathrm{yrs}$ & $53 \%$ \\
\cline { 2 - 3 } & Over 50yrs & $8 \%$ \\
\hline \multirow{4}{*}{$\begin{array}{c}\text { Monthly } \\
\text { income }\end{array}$} & Rs 4000-7000 & $20.2 \%$ \\
\cline { 2 - 3 } & Rs 7001-10000 & $8 \%$ \\
\cline { 2 - 3 } & Rs 10001 -13000 & $13.8 \%$ \\
\cline { 2 - 3 } & Rs 13001-16000 & $16 \%$ \\
\cline { 2 - 3 } & Rs 16001-19000 & $20.8 \%$ \\
\cline { 2 - 3 } & $>19001$ & $17.3 \%$ \\
\hline
\end{tabular}

The study is fully based on primary data. 300 low middle and poor people have been taken for the research in which $51(20.2 \%)$ poor whose per capita income is below $\$ 2$ per day have been taken for the analysis. Stratified and simple random sampling technique was used. There are two strata, namely low middle income families and poor families in which non-proportional allocation was made. The data were collected using 09 statements based on Liker scale. The analysis has been carried out with the use of Ordinary Least Square Method (OLS) of simple linear regression model and descriptive statistics and further Statistical Package for Social Science (SPSS) was used for the analysis. Reasons for selecting the Jaffna, Sri Lanka is that people are more educated and highly motivated to maintain their social status after post-war. In other words, they are enthusiastic to intimate others like neighbors and relatives. Jaffna district which has had 15 divisional secretariats has average household of monthly mean income of RS 18917 (Department census and statistics-DCS). The average monthly household expenditure is Rs. 22725 in which $65 \%$ for food and $35 \%$ for non-food. The poverty incidence in Jaffna is $16.1 \%$. Sample profile taken by researcher is summarized below.

\section{LITERATURE REVIEW}

Thorstein Veblen (1899) proposed that American rich were spending a significant portion of their time and money on unnecessary and unproductive leisure expenditures and coined the term conspicuous consumption to describe the behavior [1]. This linguistic construct has been used so widely that it has entered into popular English lexicon only in this particular sense of the term (Oxford English Dictionary).The wealthy individuals often consume highly conspicuous goods and services in order to advertise their wealth, thereby achieving social status[1]. In other words, Veblen (1899) introduced this concept to describe the lifestyle of members of the upper class who purchase goods and services out of necessity but instead as indicators of their wealth and status. Conspicuous consumption is lavish spending on goods and services acquired mainly for the purpose of displaying income or wealth [8]. It can also referred to a propensity towards overeating (known medically as Hyperphagia). In the mind of conspicuous consumers, such display serves as a means of attaining or maintaining social status. More recently, several economists have shown that an incorporation of a concern for social status alters results of traditional growth models [9]-[13]. People's concern for social status is important for tax policy [1], [12], [14]. Moreover, several analysis suggest that a concern for social status can sustain different social norms [14], [15]-[18]. The people consume goods and services not only to derive satisfaction from them but also to publicize their social status [19]. The consumer behavior is subject to the pressure of social norms [20]; high perceived quality luxury and prestige [5]; wealth association and intellectual properties [11]; race [21], most of the studies concentrated in some products such as mobile phone, apparel varieties, auto mobiles [22]. There is a sizable literature in economics that tries to explain the persistence of poverty. Most of this literature assumes that individuals are fully rational and that the poor like other individuals, care about their own and their offspring's future well-being, and therefore are willing to give up part of their present consumption for the sake of the future. However, as suggested by Dasgupta and Ray (1986), Banerjee and Newman (1993), credit constraints prevent the poor from passing the threshold of investment that permits a gradual escape from poverty [20], [23]. Poor families around the world spend a large fraction of their income on the consumption of goods that appear to be useless in alleviating poverty. This consumption can be interpreted as an attempt to signal status, and therefore, that the persistence of poverty may be partly due to an inefficient signaling equilibrium [24], [25]. Specifically, what is important is that there is a trade-off between conspicuous consumption and human capital as signals for unobserved income. This trade-off produces a signaling 
equilibrium in which the expected fraction of expenditure on conspicuous consumption out of total income is decreasing with human capital, which gives rise to a poverty trap [26], [27]. What is observable factor is that the conspicuous consumption belongs to not only rich consumers but also low middle and poor people. Therefore, the identification of the extent and the determinants of conspicuous consumption among the poor have important explorative character since little research has been done on this particular issue [28]-[30] .Complementary interaction can induce people to care about social status because it serve as signal of non observable abilities. There is unique separating equilibrium in which every one care about social status [31]. Individuals live in society, and many of their consumption decisions are observed by others. When making such decisions, individuals consider not only direct effects of their choice on their welfare, but also indirect effects resulting from society observing their choice. In addition to the idea that large expenditure on housing are used as signal for gaining social status, it is suggested that these narratives that one's evaluation of the adequacy of one's own living space involves comparing it with mental images of the living spaces of others. To the extent that some visibility of relevant expenditures is necessary for these narratives to be plausible [32]. Some studies with regard to conspicuous consumption explicated that some expenditures on festival leads to poverty in general. The claim that festival serve as signals of un observed wealth is supported by Bloch Rao and Desai (2004). They demonstrate, based on survey from south Indian, that daughter's marriage (dowry and celebrations) is the costliest even in the life of an Indian family and can amount to more than six times a family's annual income. It often drives parents in to severe debt at higher interest rate, and may push families in to deep poverty [33]. However, researchers in this area have not studied the phenomenon of conspicuous consumption in the context of Sri Lankan low middle and poor people. Therefore, the findings of this study may provide a valuable insight for the innovative marketers who struggle for crafting competitive strategies for their businesses.

\section{NATURE AND CONSPICUOUS CONSUMPTION IN JAFFNA, SRI LANKA}

Sri Lanka is an island found in the South East of India surrounded by Indian Ocean. This is country that abounds in natural resources and fascinating natural scenery in which total acreage of Jaffna is 1020 sq.km $(102322 \mathrm{Hec}) .35 \%$ of the land is used for agriculture and for the cultivation of cash crops. $22 \%$ of the land has been used for buildings. $5 \%$ of the land is surrounded by the lagoons, $32 \%$ of the land is surrounded by rocks, sand, marshy areas and $6 \%$ of the land is abandoned unused for cultivation. Jaffna district which has had 15 divisional secretariats has average household of monthly mean income of RS 18917 . The average monthly household expenditure is Rs.22725 in which $65 \%$ for food and $35 \%$ for non-food (Jaffna secretariat statistical hand book, 2007, 2008). The poverty incidence in Jaffna is $16.1 \%$.Jaffna has mineral resources such as salt, silicon, clay, limestone and fish and livestock. As already said, most of people are educated and they are attracted the government job because it gives minimum protection for life. In addition to government job, they engage partly in agriculture and allied work to obtain income. Jaffna has had long experience in civil war (30years).Most of the youngsters migrated to Europe such as England ,Germany, France, Norway, Sweden, Denmark ,Swiss land, and America and Canada after beginning of civil war. Now, they are citizen of such countries and sending money to their relatives and neighbors living in Jaffna. Thus, people in Jaffna are able to obtain huge money from this foreign remittance due to the exchange rate difference. For example, respondent in Jaffna can obtain RS150, 000 if somebody living in Europe send the Euro 1000 to Jaffna, But, people in Jaffna are spending these money for their conspicuous consumption even though they are poor or low middle income. Particularly, Jaffna is experiencing major shifts in her socio-cultural structure after post war. Thus, a society which has been traditionally known as "collective" in nature is showing increased evidence of individualism. With increased penetration of electronic media, affordable home entertainment systems, cinema, and the internet, consumers are opening up to the great outside world. Visual images, like elsewhere in the developed world are constantly creating reality for the consumers. This is not different in case of Jaffna. After having finished civil war, people in Jaffna are more willingness to imitate others because of seeking social status and they Strive to combat the impression that are poor. Not only that they increase his chance of making relationship with high ability and middle and upper class people.

\section{HYPOTHESIS, DATA ANALYSIS AND DISCUSSION}

The poor people, generally, are vulnerable in any shock such as increase in oil and food price, natural disaster and economic crisis. The low middle income people are clustered little above poverty line. Therefore, they are also vulnerable in any shock such as natural disaster and economic crisis. Generally, to what extent the low middle income and poor people spending on conspicuous consumption which depends upon some factors and motivation for seeking conspicuous consumption may be satisfaction or seeking equal status with people who are in well position in society. Specially, in south Asian context, female tries to imitate to other high income and socially well established peoples' consumption pattern. In sum, the purpose of this study is to shed light on the extent of the phenomenon of status consumption by middle and the poor. Therefore, we have to find out the answers for these questions. Thus, researcher has put forwarded following hypothesis

H1: the income is significant variable in determining the allocation for social status rather than sex and age.

$\mathrm{H} 2$ :.People in Jaffna is making significant allocation of their income to maintain social status than satisfaction.

H3: Conspicuous consumption among female is high that of male and poor people also significantly engage the conspicuous consumption. 
In this study, conspicuous consumption is function of three variables such as income, sex and age which is shown in following functional form.

Allocation of amount for Conspicuous consumption $=$

$\mathrm{f}$ (Income, sex, age) (1)

The equation one can be arranged in the following linear form for our purpose of study as follows

ALLOCATION $=\beta_{0}+\beta_{1} \mathrm{INCOME}+\beta_{2} \mathrm{SEX}+\beta_{3} \mathrm{AGE}+$ ut (2)

Thus an OLS regression is used on equation (2) and the results of the OLS are summarized as follows.

\begin{tabular}{|c|c|c|c|c|}
\hline \multicolumn{1}{|c|}{ TABLE II: MODEL SUMMARY } \\
Mode & $\mathrm{R}$ & R square & Adjusted R square & Std.Er.estimate \\
\hline 1 & .837 & .701 & .698 & .54819 \\
\hline
\end{tabular}

a. Predicators (constant).age, income, sex

TABLE III: COEFFICIENT

\begin{tabular}{|c|c|c|c|c|c|}
\hline Mode & \multicolumn{2}{|c|}{$\begin{array}{c}\text { Unstandarized } \\
\text { Co efficient }\end{array}$} & $\begin{array}{c}\text { Standardized } \\
\text { coeffcient }\end{array}$ & $\mathrm{t}$ & Sig \\
\cline { 2 - 4 } & $\mathrm{B}$ & Std.Error & & & \\
\hline Constant & .509 & .161 & --- & 3.12 & .002 \\
Income & .481 & & .838 & 26.3 & .000 \\
Sex & .006 & .018 & .003 & .093 & .926 \\
Age & -.003 & .065 & -.002 & -058 & .954 \\
& & .065 & & & \\
& & -.044 & & & \\
\hline
\end{tabular}

H1: the income is significant variable in determining the allocation for social status rather than sex and age.

The summarized results of regression are shown in table 2 and 3. The value of $\mathrm{R}^{2}$ of 0.701 means that about 70 percent of the variation in allocation of their income for status seeking is explained by above three variables such as income of respondents, sex and age. In other words, high $\mathrm{R}^{2}$ (0.70) indicates the statistical fitness of the model used to analyze the determinants of allocation of income for status seeking in the society. In accordance with above regression result, income of the consumer (respondent) significantly affects the amount of income to be allocated for status seeking and there is positive relationship between income and allocation of income for status seeking. Thus, as income of respondent increases, allocation of income in the total income for status seeking also increases because he wants to have more allocation for status seeking. The main reasons is that people strived to imitate to their relatives and high income groups and they feel themselves they are becoming better off than before. According to regression result, as income of respondent increases by $100 \%$, amount to be allocated for status seeking will increase by $48 \%$ when other variables like age and sex remain constant and vice versa. Nevertheless, income of respondent has played significant and positive impact on amount to be allocated for status seeking. Conversely, sex has the impact on the allocation of income for status seeking but not significant. Age has insignificant and negative impact on the amount to be allocated for status seeking in the society. According to the survey findings, youngsters are more willing and enthusiastic to maintain the social status. Therefore, the result brings the light the fact that income is main determinant of the amount to be allocated for social status. At the same time, even though sex and age also affect the decision of amount allocation for social status, they have insignificant impact on the amount to be allocated for social status.

H2: People in Jaffna are making significant allocation of their income to maintain social status than satisfaction

TABLE IV: AllocATION AND PURPOSE CROSS TABULATION

\begin{tabular}{|c|c|c|c|c|}
\hline \multicolumn{2}{|c|}{} & $\begin{array}{c}\text { purpose } \\
\text { satisfaction }\end{array}$ & purpose status & total \\
\hline Allocation & $<5 \%$ & 43 & 30 & 73 \\
\hline & $5-10 \%$ & 30 & 63 & 93 \\
\hline & $10-15 \%$ & 15 & 76 & 91 \\
\hline & $\begin{array}{c}15-30 \% \\
\text { or }>30\end{array}$ & 7 & 36 & 43 \\
\hline \multicolumn{2}{|c|}{ Total } & 95 & 205 & 300 \\
\hline
\end{tabular}

TABLE V: ALLOCATION AND INCOME CROSS TABULATION

\begin{tabular}{|c|c|c|c|c|c|c|c|c|}
\hline & & \multicolumn{6}{|c|}{ income } & \multirow{2}{*}{$\begin{array}{c}\text { Tota } \\
1\end{array}$} \\
\hline & & $\begin{array}{c}400 \\
0- \\
700 \\
0\end{array}$ & $\begin{array}{c}7001 \\
- \\
1000 \\
0\end{array}$ & $\begin{array}{c}1000 \\
1- \\
1300 \\
0\end{array}$ & $\begin{array}{c}1300 \\
1- \\
1600 \\
0\end{array}$ & $\begin{array}{c}1600 \\
1- \\
1900 \\
0\end{array}$ & $\begin{array}{c}> \\
190 \\
01\end{array}$ & \\
\hline \multirow[t]{4}{*}{$\begin{array}{l}\text { Alloc } \\
\text { ation }\end{array}$} & $<5 \%$ & 48 & 13 & 9 & 1 & 2 & 0 & 73 \\
\hline & $5-10 \%$ & 3 & 9 & 30 & 37 & 12 & 2 & 93 \\
\hline & $\begin{array}{c}10- \\
15 \% \\
\end{array}$ & 0 & 3 & 2 & 13 & 54 & 20 & 92 \\
\hline & $\begin{array}{c}15- \\
30 \% \\
\text { or }>30\end{array}$ & 0 & 0 & 2 & 1 & 0 & 39 & 42 \\
\hline \multicolumn{2}{|c|}{ Total } & 51 & 25 & 43 & 52 & 68 & 61 & 300 \\
\hline
\end{tabular}

In accordance with table $4,14 \%$ respondents allocate less than $5 \%$ of income for the purpose of satisfaction, and $10 \%$ for status seeking. But, $21 \%$ respondents allocate $5-10 \%$ of income for status seeking and only $10 \%$ for satisfaction. Likewise $25.3 \%$ respondents allocate $10-15 \%$ of income for maintaining social status and $14 \%$ respondents allocate 15 $31 \%$ or more than $30 \%$ for status seeking. Further, it can briefly be stated that $68 \%$ respondents in the out of total respondents are allocating their income for maintaining social status and to combat the impression that they are poor. As already defined, those who are getting income between 4000-7000 are poor in the society (World bank poverty line is $\$ 2$ per day, exchange rate is around $\$ 1=\mathrm{RS} 110$ 120).The $94 \%$ poor (out of total poor people) are willingness to spend less than $5 \%$ income for both satisfaction and status seeking (see table 5). Therefore, this statistics clearly prove the fact that people in Jaffna are making significant allocation of their income to maintain social status than satisfaction

H3: Conspicuous consumption among female is high that of male and poor people also significantly engage the conspicuous consumption.

In consonance with Table VI, 65.3\% male respondents accepted that they engage and allocate part of their income for conspicuous consumption for status seeking motive. Only $32 \%$ male respondents expressed the view that they do not engage in conspicuous consumption. Conversely, the 
table 6 clearly shows the fact that $75.8 \%$ female respondents engage the conspicuous consumption for status seeking motives. According to the table 7, out of male respondents, $53 \%$ of male respondents allocate $5-15$ percentage of their income for conspicuous consumption and $67.5 \%$ of female respondents allocate 5-15percentage of their income for conspicuous consumption. Therefore what is observable from above descriptive statistics is that even though female respondents engaged little bit higher than that of male, there is no considerable differences between male and female in engaging the conspicuous consumption.

TABLE VI: SEX AND CONSPICUOUS CONSUMPTION CROSS TABULATION

\begin{tabular}{|c|c|c|c|c|}
\hline \multicolumn{2}{|c|}{} & \multicolumn{2}{|c|}{ con.consumption } & \multirow{2}{*}{ Total } \\
\cline { 3 - 4 } \multicolumn{2}{|c|}{} & yes & no & \\
\hline \multirow{2}{*}{ sex } & male & 122 & 58 & 180 \\
\cline { 2 - 4 } & female & 91 & 29 & 120 \\
\hline \multicolumn{2}{|c|}{ Total } & 213 & 87 & 300 \\
\hline
\end{tabular}

TABLE VII: SEX AND ALLOCATION CROSS TABULATION

\begin{tabular}{|c|c|c|c|c|}
\hline \multicolumn{2}{|c|}{} & \multicolumn{2}{|c|}{ Sex } & \multirow{2}{*}{ Total } \\
\cline { 2 - 5 } & \multicolumn{2}{|c|}{ Male } & Female & \\
\hline \multirow{3}{*}{ Allocation } & $<5 \%$ & 47 & 30 & 77 \\
\cline { 2 - 5 } & $5-10 \%$ & 55 & 36 & 91 \\
\cline { 2 - 5 } & $10-15 \%$ & 47 & 45 & 92 \\
\cline { 2 - 5 } & $\begin{array}{c}15-30 \% \\
\text { or }>30\end{array}$ & 31 & 9 & 40 \\
\hline \multicolumn{2}{|c|}{ Total } & 180 & 120 & 300 \\
\hline
\end{tabular}

TABLE VIII: CON.CONSUMPTION AND POOR PEOPLE CROSS TABUlation

\begin{tabular}{|c|c|c|c|c|}
\hline \multicolumn{2}{|c|}{} & \multicolumn{2}{|c|}{ Person } & \multirow{2}{*}{ Total } \\
\cline { 3 - 5 } & poor & middle & \\
\hline \multirow{2}{*}{ con.consumption } & yes & 21 & 184 & 205 \\
\cline { 2 - 5 } & no & 30 & 65 & 95 \\
\hline \multicolumn{2}{|c|}{ Total } & 51 & 249 & 300 \\
\hline
\end{tabular}

In consonance with Table VIII, 41.2 percentage of poor respondents accepted that they engage the conspicuous consumption for the reasons that may be status or satisfaction. 58.8 percentages of poor respondents do not accept that they engage conspicuous consumption for status seeking or satisfaction. But what is observable fact from above data is that significant percentages of poor are engaging conspicuous consumption even though they are struggling lack of income. This finding clearly shows the fact that People in Jaffna are more enthusiastic to have conspicuous consumption. Because, they strive to prove themselves that they are well position in a society and better off than before whether income is enough or not.

\section{CONCLUSIONS}

Jaffna, Sri Lanka is experiencing major shifts in her socio-cultural structure during the last ten years, especially after post war. This study clearly indicates that people in Jaffna are more enthusiastic to imitate others because of seeking social status and also they Strive to show the impression that they are better off than before. Not only that they increase his chance of making relationship with high ability and middle and upper class people. The value of $\mathrm{R}^{2}$ of 0.701 indicating statistical fitness of the model clearly shows that 70 percent of the variation in allocation of their income for status seeking is explained by above three variables such as income of respondents, sex and age in which as income of respondent increases by $100 \%$, amount to be allocated for status seeking has increased by $48 \%$.Thus, the results bring to light the fact that income is main determinant of the amount to be allocated but sex and age have insignificant impact on the amount to be allocated for social status. Further, $65.3 \%$ male and $75.8 \%$ female respondents accepted that they engage and allocate part of their income for conspicuous consumption for status seeking motive .The out of male respondents, $53 \%$ of male respondents allocate 5-15 percentage of their income for conspicuous consumption and $67.5 \%$ of female respondents allocate 5-15percentage of their income for conspicuous consumption .41 .2 percentage of poor respondents also accepted that they engage the conspicuous consumption for the reasons that may be status or satisfaction Therefore, this findings clearly show the fact that middle income people in Jaffna are making significant allocation of their income to maintain social status and at the same time, poor people in Jaffna are also enthusiastic to have conspicuous consumption for expressing their position that they are better off than before. This study will be giving different insight to researchers and policy makers because the literature for conspicuous consumption pays little attention on poor and low middle income people yet, especially in Sri Lanka. Further this study will help to marketing managers or firms in their decision about sales.

\section{REFERENCE}

[1] T. Veblen, Theory of the Leisure Class: An Economic Study in the Evolution of Institutions, New York, 1899.

[2] J. M. Keynes, The general theory of Employment interest and money, Macmillan Cambridge University Press ,1936.

[3] C. Namazie and P. Sanfey, "Happiness and transition: the case of Kyrgyzstan," Review of Development Economics, vol. 5, no.3, pp. 392-405, 2001.

[4] N. Powdthavee, "Is the structure of happiness equations the same in poor and rich countries?: the case of South Africa," Unpublished manuscript, Dept of Economics, University of Warwick, 2003.

[5] J. Duensberry, "Income, saving and the theory of consumer behavior," Harvard University Press, Cambridge, 1949.

[6] C. Graham and S. Pettinato, "Frustrated achievers: winners, losers and subjective well-being in new market economies," Journal of Development Studies, vol. 38, no. 4, pp.100-140, 2002.

[7] F. Piron, "Consumers' perceptions of the country-of-origin effect on purchasing intentions of (in) conspicuous products," Journal of Consumer Marketing, vol.17, no.4, pp.308-320, 2000.

[8] W. Pesendorfer, "Design Innovation and fashion cycles," American Economic Review, vol. 85, pp771-792, 1995.

[9] H. L. Cole and G. J. Mailath Postlewaite, "Social norms, Saving behavior and growth," Journal of Political Economy, vol.100, pp.1092-1125, 1992.

[10] C. Fershtman, K. M. Murphy, and Y. Weiss, "Social Status, education, and growth," Journal of Political Economy, vol. 104, pp.108-132, 1996.

[11] M. Rauscher, "Protestant Ethic, Status Seeking, and Economic Growth," Thunen Series Working Paper no. 9, Rostock Univ., Rostock, 1997.

[12] G. Corneo and O. Jeanne, "Social organization in an endogenous growth model," International Economic Review, vol.40, pp.711-725, 1999. 
[13] K. A. Brekke and R. Howarth Status, "Growth and the Environment: Goods as Symbols in Applied Welfare Economics," Edward Elgar Publishing: Cheltenham, 2002.

[14] D. M. Bernheim, "A theory of conformity," Journal of Political Economy, vol. 102, pp.84-187,1994.

[15] A. Akerlof, "A theory of Social Custom, of which unemployment may be one consequence," The Quarterly Journal of Economics, vol.94, pp. $749-775,1980$.

[16] A. Lindbeck, "Incentives and social norms in household behavior," American Economic Review, vol. 87, pp.370-377, 1997.

[17] H. Holl Ander, "A social exchange approach to voluntary cooperation," American Economic Review, vol. 80, pp.1157-1167, 1990.

[18] A. Chao, and J. B. Schor, "Empirical Tests of Status Consumption: Evidence from Women's Cosmetics," Journal Of Economic psychology, vol. 19, no.1, pp. 107-131,1998.

[19] G. Stigler and G. Becker, "DE Gustibus Non Disputandum," American Economic Review, vil.67, no. 2, pp.76-89,1977.

[20] P. Dasgupta and D. Ray, "Inequality as a Determinants of Malnutrition and Unemployment policy," Economic journal, vol.96, pp.1011-1034, 1986.

[21] K. K. Charles, E. Hurst, and N. Roussanov, "The transition to home ownership and the Black- White wealth Gap," The review of Economics and Statistics, vol. 84, no. 2, pp. 281-297, 2007.

[22] K. Eastman, E. Goldsmith, and F. Reinecke Flynn, "Status consumption in consumer behaviour: scale development and validation," Journal of Marketing Theory and Practice, vol. 7, no.3, pp.41-52,1999

[23] A. Banerjee and A. Newman, "Occupational choice and the process of development," Journal of Political Economy, vol.101, pp.274-98, 1993.

[24] J. S. Tomasand and D. D. William, The Millionaire Next Door, Simon and Schuster, pp.234, 1988.

[25] P. Shukla, "Status consumption in cross-national context: Sociopsychological, brand and situational antecedents," International Marketing Review, vol.27, no.1, pp.108-129,2010.

[26] M. Rauscher, "Conspicuous Consumption, Economic Growth and Taxation," Journal of Economics, vol.66, no. 1. pp. 35-42, 1997.

[27] L. S. Bagwell and D. M. Bernheim, "Veblen effects in a theory of conspicuous Consumption," American Economic Review, vol. 86, no.3, pp. 349-373,1996.

[28] G. S. Becker and N. Tomas, "An Equilibrium Theory of the Distribution of Income and Intergenerational Mobility," Journal of Political Economy, vol.87, pp. 1153-89, 1979.

[29] O. Galor and J. Zeira, "Income Distribution and Macroeconomics," Review of Economic Studies, vol.60, pp. 35-52.1993.

[30] O'Cass Aron and H. McEwen, "Exploring consumer status and conspicuous consumption," Journal of Consumer Behaviour, vol. 4, no.1, pp. 25-39, 2004.

[31] R. Mason, "Conspicuous Consumption and the Positional Economy: Policy and Prescription since 1970," Managerial and Decision Economics, vol. 21, no.3, pp. 123-132, 2000.

[32] R. Mari, "Why people care about social status," Journal of Economic Behavior and Organization, vol. 66, pp. 233- 242, 2008.

[33] R. H. Frank, Luxury Fever, Free New York, p.131

[34] B. F. V. Rao and S. Desai, "Wedding celebrations as conspicuous consumption: Signaling social status in Rural India," The Journal of Human Resources, vol. 39, pp. 675-695,2006.

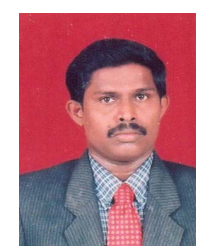

Sinnathurai Vijayakumar was born in Jaffna,Sri Lanka on 17.10.1970. He did B.A in Economics in the Jaffna university and successfully completed his M.A in the university of Mysore, India and M.PHIL in university of Madras. He has been working as SENIOR LECTURER in department of economics, the university of Jaffna, Sri Lanka since 2000. Now , he is proceeding with his PHD in the Tomas Bata University, Czech Republic. he authored three books which are as follows:

1.Macroeconomics :theory and policy, Jaffna, Thurai pathipagam,2008 2.Micro and Macro economic theories, Semamadu publication,Colombo,2009.

3.Conventional life of Karaveddy, Jaffna, Thurai Pathipakam,2010

He has done the research in poverty, fiscal policy, international trade, sustainable development, and macroeconomics. He is currently doing research on the role of small medium enterprises in the changing poverty status.

$\mathrm{He}$ is a member of IEDRC, Honk Kong and life member of Jaffna science association, Sri Lanka.

\begin{tabular}{|c|c|c|}
\hline Degree & Institution & Year \\
\hline $\begin{array}{c}\text { 1.B.A development } \\
\text { economics }\end{array}$ & $\begin{array}{c}\text { Universityof Jafffna, } \\
\text { Sri Lanka }\end{array}$ & 1996 \\
\hline 2.M.A economics & $\begin{array}{c}\text { University of Mysore, } \\
\text { India }\end{array}$ & 2004 \\
\hline 3.M.Phil economics & $\begin{array}{c}\text { University of Madras, } \\
\text { India }\end{array}$ & 2005 \\
\hline
\end{tabular}

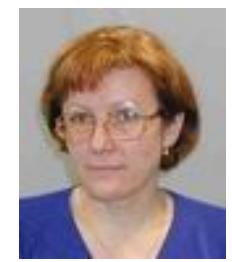

Prof. Olga Brezinona was born in Kyjovice ,Czech Republic on 03.03.1954. She obtained Doctoral degree in Economics, Slovak Academy of Sciences, Bratislava, Slovak Republic in 1988 and She became Assistant professor in economics, VSB - Technical University of Ostrava, Czech Republic, 1995.

She is a university lecturer from 1978 VSB-

TUO, Ostrava, CR (1978 - 1995 ASSISTANT, 1995 - 2008 ASSISTANT PROFESSOR and , 1999 - 2005 VICE-DEAN), Silesian University, Opava, CR (2008 - 2010 ASSISTANT PROFESSOR, LECTURER) .She is working as a Assistant Professor in Tomas Bata University, Zlin from 1996 (1996 till now, part-time Assistant Professor and Ph.D. SUPERVISOR)

She is working as Assistant professor in Karel Englis University, Brno from 2011 (2011 till now Assistant professor).

She published many research articles in ethics in economics, theory and practice of antitrust regulation and corporate social responsibility. She is interested in doing research in following field such as corporate social responsibility, decision making under imperfect information, methodology of economics, ageing population, ethics in economics Prof. Brezinova is Member of scientific Board of Tomas Bata University in Zlin, CR, Member of scientific board of Faculty PEDAS, University of Zilina, Slovak Republic, Member of academic board of Karel Englis University, Brno, CR, Member of commissions for doctoral theses defenses at Tomas Bata University and Silesian University. 